\title{
Effects of the mechanical damage on the water absorption process by corn kernel
}

\author{
Fernando Mendes BOTELHO ${ }^{1 \star}$, Paulo Cesar CORREA², Márcio Arêdes MARTINS², \\ Sílvia de Carvalho Campos BOTELHO ${ }^{3}$, Gabriel Henrique Horta de OLIVEIRA ${ }^{4}$
}

\begin{abstract}
The purpose of this study was to investigate and model the water absorption process by corn kernels with different levels of mechanical damage Corn kernels of AG 1510 variety with moisture content of 14.2 (\% d.b.) were used. Different mechanical damage levels were indirectly evaluated by electrical conductivity measurements. The absorption process was based on the industrial corn wet milling process, in which the product was soaked with a $0.2 \%$ sulfur dioxide $\left(\mathrm{SO}_{2}\right)$ solution and $0.55 \%$ lactic acid $\left(\mathrm{C}_{3} \mathrm{H}_{6} \mathrm{O}_{3}\right)$ in distilled water, under controlled temperatures of $40,50,60$, and $70{ }^{\circ} \mathrm{C}$ and different mechanical damage levels. The Peleg model was used for the analysis and modeling of water absorption process. The conclusion is that the structural changes caused by the mechanical damage to the corn kernels influenced the initial rates of water absorption, which were higher for the most damaged kernels, and they also changed the equilibrium moisture contents of the kernels. The Peleg model was well adjusted to the experimental data presenting satisfactory values for the analyzed statistic parameters for all temperatures regardless of the damage level of the corn kernels.
\end{abstract}

Keywords: Peleg's Equation; wet milling process; steeping.

\section{Introduction}

Steeping (soaking or hydration) is a very important operation in the processing of some agricultural products (such as wheat, corn, rice, and soybean) due to the morphological and biochemical changes that occur and are responsible for all subsequent stages and, therefore, for the final quality of the product. In the case of corn, this kind of processing aims to separate the corn kernels into their basic components (starch, protein, yeast, and fibers).

Commercially, the kernels are soaked with a 0.1 to $0.2 \%$ sulfur dioxide $\left(\mathrm{SO}_{2}\right)$ solution, and $0.55 \%$ lactic acid $\left(\mathrm{C}_{3} \mathrm{H}_{6} \mathrm{O}_{3}\right)$ in water for a period of time that might vary from 24 to 60 hours under controlled temperature between 45 and $55^{\circ} \mathrm{C}$ (DOWD, 2003; LOPES FILHO; RAMOS; ROMERO, 2006; PEREZ et al., 2003).

There are many studies on the steeping stage in the conventional industrial wet milling process of corn kernels which have investigated the factors that affect the yield and the quality of the starch and the water diffusion into the kernels such as temperature and process time; drying temperature of the kernel, size of the particle; and concentration of lactic acid; and sulfur dioxide in the soaking solution. Those studies have also contributed to the software development and modeling of this process (HAROS; SUAREZ, 1997; PEREZ et al., 2003; HAROS; TOLOBA; SUAREZ, 2003; HAROS et al., 2006; LOPES FILHO; RAMOS; ROMERO, 2006; RAMIREZ et al., 2008; MENDES; RESENDE; ALMEIDA, 2011). However, although being already known as the stage that demands more time in the wet milling process, mainly due to physical limitations imposed by the pericarp and the internal structure of the kernel, there are only a few studies on steeping available in the specialized literature relating the absorption phenomenon to the damage level suffered by the corn kernels.

Therefore, the purpose of this study was to verify the influence of the mechanical damage in corn kernels on the water absorption process by modeling the water soaking process by corn kernels with different damage levels under different temperatures.

\section{Materials and methods}

\subsection{Raw material}

Corn kernels of AG 1510 variety were used in this experiment. They were acquired from a rural producer from Viçosa (MG), Brazil. The kernels were manually harvested and dehulled in order to avoid mechanical damage. After that, they were submitted to a cleaning process using sieves to separate impurities, defective, and damaged kernels and other materials.

The initial moisture content of the product was 25.0 (\% d.b.), and it was submitted to drying under controlled conditions with the air temperature at $45^{\circ} \mathrm{C}$ until reaching a moisture content of 14.2 (\% d.b.). The moisture content was determined in an oven with air forced circulation at $105 \pm 1{ }^{\circ} \mathrm{C}$ for 24 hours in three samples of $40 \mathrm{~g}$ each one, according to Brasil (1992), with modifications.

\footnotetext{
Received 16/7/2012

Accepted 14/2/2013 (005748)

Universidade Federal de Mato Grosso - UFMT, Av. Alexandre Ferronato, 1200, Distrito Industrial, CEP 78557-267, Sinop, MT, Brasil,

e-mail:fernando.eaa@gmail.com

${ }^{2}$ Departamento de Engenharia Agrícola, Universidade Federal de Viçosa - UFV, CEP 36570-000, Viçosa, MG, Brasil

3 Embrapa Agrossilvipastoril, CPAMT, CEP 78550-000, Sinop, MT, Brasil

${ }^{4}$ Instituto Federal de Educação, Ciência e Tecnologia de Brasília, IFB, Lote 01 - DF 480, Gama, DF, Brasil

${ }^{*}$ Corresponding author
} 


\subsection{Mechanical damage}

In order to induce mechanical damage in the corn kernels, a Stein Breakage Tester (model CK2-M, Fred Stein Laboratories, Inc., United States of America) was used. This device has a steel cylinder and a central blade with a constant rotation of 1,800 rpm, which throws the kernels against the cylinder walls thus causing impact and abrasion effort. The corn samples were submitted to mechanical damage at the times of 0 (evidence), $1,2,3$, and 4 minutes.

The level of mechanical damage was indirectly assessed by the electrical conductivity of the exuded corn kernel. For this test, four sub-samples of fifty kernels from each treatment were counted and collected. The samples were placed in plastic cups containing $75 \mathrm{~mL}$ of deionized water and kept in a chamber under controlled temperature at $25{ }^{\circ} \mathrm{C}$ for 24 hours. Next, electrical conductivity measurements were carried out in the solutions with the samples using a portable conductivimeter (Digimed model DM3, Brazil).

The levels of mechanical damage found in the corn samples used in the soaking process were: 2.847 (control); 14.077; 22.261 ; 29.194; and $32.971 \mu \mathrm{S} \mathrm{cm}^{-1} \mathrm{~g}^{-1}$.

\subsection{Hydration of the corn kernels}

For the hydration process, the samples containing $40 \mathrm{~g}$ of kernels were used in three repetitions. These samples were placed in hermetically-sealed vials of $150 \mathrm{~mL}$ containing a solution of $0.2 \%$ sulfur dioxide $\left(\mathrm{SO}_{2}\right)$ and $0.55 \%$ lactic acid $\left(\mathrm{C}_{3} \mathrm{H}_{6} \mathrm{O}_{3}\right)$ in distilled water resulting in a ratio between the product and solution of around 1:3. The solution and the ratio used for the hydration process (at least 1:2) refer to the conventional steeping stage that the corn is submitted to the wet milling process. The solution was obtained by adding $5.9 \mathrm{~g}$ of sodium metabisulfite $\left(\mathrm{Na}_{2} \mathrm{~S}_{2} \mathrm{O}_{5}\right)$ and $11 \mathrm{~mL}$ of acid lactic $\left(\mathrm{C}_{3} \mathrm{H}_{6} \mathrm{O}_{3}\right)$ to $2 \mathrm{~L}$ of distilled water (LOPES FILHO; RAMOS; ROMERO, 2006).

The samples were submitted to soaking at controlled temperatures of $40,50,60$, and $70^{\circ} \mathrm{C}$, and their moisture content was measured by difference in mass during the process. Mass was determined using digital scales with a resolution of $0.01 \mathrm{~g}$ in predetermined intervals of time of 12 hours or until the kernel reached its equilibrium moisture content. A set of three independent samples was used for each reading time.

\subsection{Modeling of hydration process}

In order to evaluate and model the hydration process of the corn kernels at the different proposed temperatures, the Peleg empiric model was used (PELEG, 1988), as described in Equation 1. This is a non-exponential model of two parameters, which was satisfactorily used by several researchers in order to predict the absorption kinetics in several kinds of food, such as beans (RESENDE; CORRÊA, 2007), chickpea (TURHAN; SAYAR; GUNASEKARAN, 2002), amaranth (RESIO; AGUERRE; SUAREZ, 2006), sorghum (KASHIRI; KASHANINEJAD; AGHAJANI, 2010), and wheat (MASKAN, 2002; VENGAIAH et al., 2012) or industrialized products, such as penne pasta (CUNNINGHAM; McMINN; RICHARDSON, 2007).

$U_{t}^{*}=U_{0}^{*} \pm \frac{t}{\left(C_{1}+C_{2} t\right)}$

where: $U_{t}^{*}$ is the moisture content at any time, \% d.b.; $U_{0}^{*}$ is the initial moisture content, $\%$ d.b.; $t$ is the time, $h ; C_{1}$ is Peleg's rate constant, $100 \mathrm{~h} \mathrm{~kg} \mathrm{~kg}^{-1}$; and $C_{2}$ is the Peleg's capacity constant, $100 \mathrm{~kg} \mathrm{~kg}^{-1}$.

The plus-minus signal $( \pm)$ in Equation 1 means that the model might be used both in absorption or adsorption processes $(+)$, as well as in desorption processes (-).

The constants $C_{1}$ e $C_{2}$ of the proposed in the water absorption model by corn kernels were obtained by the adjustment in the linearized Peleg's Equation, as described in Equation 2.

$\frac{t}{U_{t}^{*}-U_{0}^{*}}=C_{1}+C_{2} t$

One of the advantages of the Peleg model is gaining time for predicting the kinetics of water absorption in food, including the prediction of the equilibrium moisture contents (PELEG, 1988) which might be obtained by Equation 1 when time tends to infinity, resulting in Equation 3:

$U_{e}^{*}=U_{0}^{*}+\frac{1}{C_{2}}$

where: $U_{e}^{*}$ is the equilibrium moisture content ( $\%$ d.b.).

\subsection{Statistical analysis of the model}

In order to verify the level of adjustment of the model, the magnitudes of the determination coefficient $\left(R^{2}\right)$, the mean relative percent deviation $(P)$, and the standard error of estimate $(S E)$ were considered. The values of the relative percent deviation and the standard error of estimate for each model were respectively calculated by Equations 4 and 5:

$P=\frac{100}{\eta} \sum \frac{|Y-\hat{Y}|}{Y}$

$S E=\sqrt{\frac{\sum(Y-\hat{Y})^{2}}{G L R}}$

where: $Y$ is the experimentally observed value; $\hat{Y}$ is the value estimated by the model; $\eta$ is the number of observed data; and GLR are the degrees of freedom of the residue (number of observed data minus the number of parameters of the model).

\section{Results and discussion}

\subsection{Water absorption}

The values of moisture content of corn kernels found during the soaking process are shown in Figure lunder different temperatures and mechanical damage levels of the product used. 

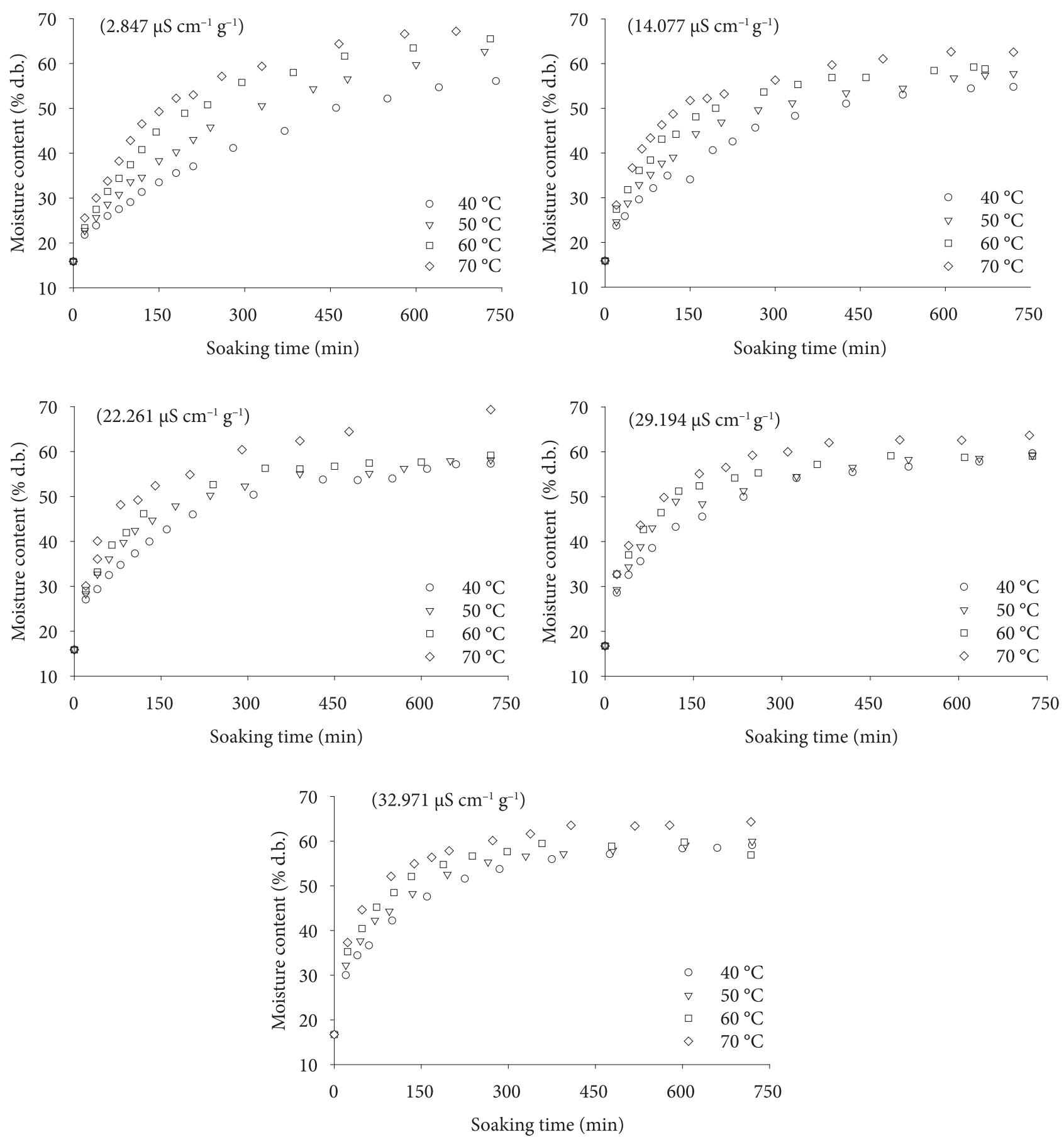

Figure 1. Moisture content values of corn kernels during the soaking process under different temperatures and mechanical damage levels.

As shown in Figure 1, the corn kernels had a water absorption characteristic behavior during the soaking process. The beginning of the process shows a high rate of water absorption with a decreasing trend over time as the product got closer to its equilibrium moisture content (BELLO; TOLABA; SUAREZ, 2004; YILDIRIM; ÖNER; BAYRAM, 2011; RESIO; AGUERRE; SUAREZ, 2006; VENGAIAH et al., 2012). Bello, Tolaba and Suarez (2004) suggested that this fact might be attributed to the fast water absorption by capillary vessels of the external layers of the pericarp, thus causing a fast increase in the moisture content of the product, with a decreasing trend to saturation. Another factor that could be attributed to the high initial absorption rates would be the high gradient of moisture content in the several tissues of the kernel and the environment.

It may be also observed that the effect of the temperature on water absorption was more evident for the corn with low indexes of mechanical damage (2.847 and $14.077 \mu \mathrm{S} \mathrm{cm} \mathrm{cm}^{-1} \mathrm{~g}^{-1}$ ). Under these conditions, it is possible to notice that there is a regular increase in the amount of water absorbed for similar temperature increases. However, it is not possible to distinguish the variation in the moisture content values in relation to the temperatures 
of 40,50 , and $60^{\circ} \mathrm{C}$ of the corn kernels with higher mechanical damage levels $\left(22.261,29.194\right.$ and $\left.32.971 \mu \mathrm{cm}^{-1} \mathrm{~g}^{-1}\right)$, mostly after the first three hundred minutes of the test. For these temperatures, due to the mechanical damage level, the kernels showed a trend to reach the same equilibrium moisture content. Temperature is considered the major factor that affecting the amount of water absorbed during soaking (MUÑOZ et al., 2012; VENGAIAH et al., 2012; YILDIRIM; ÖNER; BAYRAM, 2010, 2011); however, as observed in this study, other factors, such as the physical integrity of the product, might significantly affect water absorption.

According to Figure 1, it was observed that only for the temperature of $70{ }^{\circ} \mathrm{C}$ it was possible to distinguish the moisture content variation in the corn kernels, regardless of the damage level. For this condition, there was a higher rate of water absorption regardless of absorption temperature or physical integrity of the product. Maskan (2002) observed a similar behavior studying the soaking process in wheat and its by-products and attributed to this behavior the fact that wheat, at such temperature would have already reached the starch gelatinization that allows us to suggest that the gelatinization temperature of the corn samples used in this study are between 60 and $70{ }^{\circ} \mathrm{C}$. This result was in accordance with those found by Souza and Andrade (2000) and Yildirim, Öner and Bayram (2010), who found gelatinization temperature of starch corn and chickpeas is of 70 and $60^{\circ} \mathrm{C}$, respectively.

The gelatinization process, which mainly happens in starchy products when they reach the gelatinization temperature, causes a rupture in the crystalline structure of the starch granules, and they start to become tumid and form considerably viscous solutions causing excess of water in the kernel. In addition, due to the starch gelatinization, physical damages such as cracks might be reconstituted, thus minimizing the effect of the physical integrity in the water absorption process.

\subsection{Peleg model performance in describing the water absorption phenomenon}

Figure 2 shows the values obtained and the values that were estimated by linearized Peleg model (Equation 2) of the variations in the moisture content values of corn kernels with different mechanical damage levels during the hydration process for the different temperatures .

It can be seen in Figure 2, that the Peleg model was well adjusted to the observed data for all combinations of temperature and mechanical damage levels of the corn kernels, which can be confirmed by the magnitudes of the statistical parameters shown in Table 1.

According to the data shown in Table 1, it was observed that the adjustment of the Peleg model presented values of the coefficient of determination above $99 \%$, and that the $p$-value for all coefficients (probability of the null hypothesis being true) was less than 0.0001 for all conditions, which according to Resio, Aguerre and Suarez (2006), indicates a good adjustment of this model to the experimental data. Values of the coefficient of determination above $99 \%$ are satisfactory, considering the Peleg model (CUNNINGHAM; McMINN; RICHARDSON, 2007; VASUDEVA; VISHWANATHAN, 2010); however, this coefficient should not be used isolatedly as an evaluation

Table 1. Values of standard error of estimate $(S E)$, mean relative percent deviation $(P)$, determination coefficient $\left(\mathrm{R}^{2}\right)$, and coefficients $\left(C_{1}\right.$ and $\mathrm{C}_{2}$ ) of the Peleg model obtained by adjustment to the experimental data for the soaking of the corn kernels under different mechanical damage levels in different temperatures.

\begin{tabular}{|c|c|c|c|c|c|c|}
\hline $\mathrm{CE}\left(\mu \mathrm{S} \mathrm{cm}^{-1} \mathrm{~g}^{-1}\right)$ & $\mathrm{T}\left({ }^{\circ} \mathrm{C}\right)$ & $C_{1}\left(100 \mathrm{~h} \mathrm{~kg} \mathrm{~kg}^{-1}\right)$ & $C_{2}\left(100 \mathrm{~kg} \mathrm{~kg}^{-1}\right)$ & SE (\% d.b.) & $\mathrm{P}(\%)$ & $\mathrm{R}^{2}(\%)$ \\
\hline \multirow{4}{*}{2.847} & 40 & $0.098007^{* * *}$ & $0.016764^{* * *}$ & 1.529 & 2.59 & 99.30 \\
\hline & 50 & $0.065200^{\star * *}$ & $0.016309^{* * *}$ & 1.267 & 2.04 & 99.60 \\
\hline & 60 & $0.046385^{\star * *}$ & $0.016237^{\star * *}$ & 0.870 & 1.25 & 99.84 \\
\hline & 70 & $0.036132^{* * *}$ & $0.016095^{* * *}$ & 1.111 & 1.59 & 99.73 \\
\hline \multirow{2}{*}{14.077} & 40 & $0.055591^{\star * *}$ & $0.021021^{\star * \star}$ & 1.308 & 2.00 & 99.44 \\
\hline & 50 & $0.039202^{* * *}$ & $0.020813^{* * *}$ & 0.958 & 1.44 & 99.70 \\
\hline \multirow{4}{*}{22.261} & 40 & $0.038892^{* * *}$ & $0.021215^{* * *}$ & 1.792 & 2.38 & 99.45 \\
\hline & 50 & $0.028467^{\star * *}$ & $0.021476^{\star * *}$ & 1.246 & 1.65 & 99.91 \\
\hline & 60 & $0.023805^{\star * *}$ & $0.021219^{* * *}$ & 1.120 & 1.29 & 99.95 \\
\hline & 70 & $0.016301^{\star * *}$ & $0.019685^{\star * *}$ & 2.509 & 3.06 & 99.57 \\
\hline 29.194 & 40 & $0.029803^{\star * *}$ & $0.021645^{\star * \star}$ & 1.627 & 2.10 & 99.63 \\
\hline \multirow{4}{*}{32.971} & 40 & $0.025485^{\star * *}$ & $0.021569^{* * *}$ & 1.582 & 2.03 & 99.23 \\
\hline & 50 & $0.019928^{* * *}$ & $0.021607^{\star * *}$ & 1.506 & 1.60 & 99.81 \\
\hline & 60 & $0.014727^{\star * *}$ & $0.021640^{* * *}$ & 1.242 & 1.46 & 99.48 \\
\hline & 70 & $0.013297^{\star * *}$ & $0.019896^{* * *}$ & 1.064 & 1.13 & 99.67 \\
\hline
\end{tabular}

${ }^{* * *}$ p-value $<0.0001$ (probability of the null hypothesis being true) 

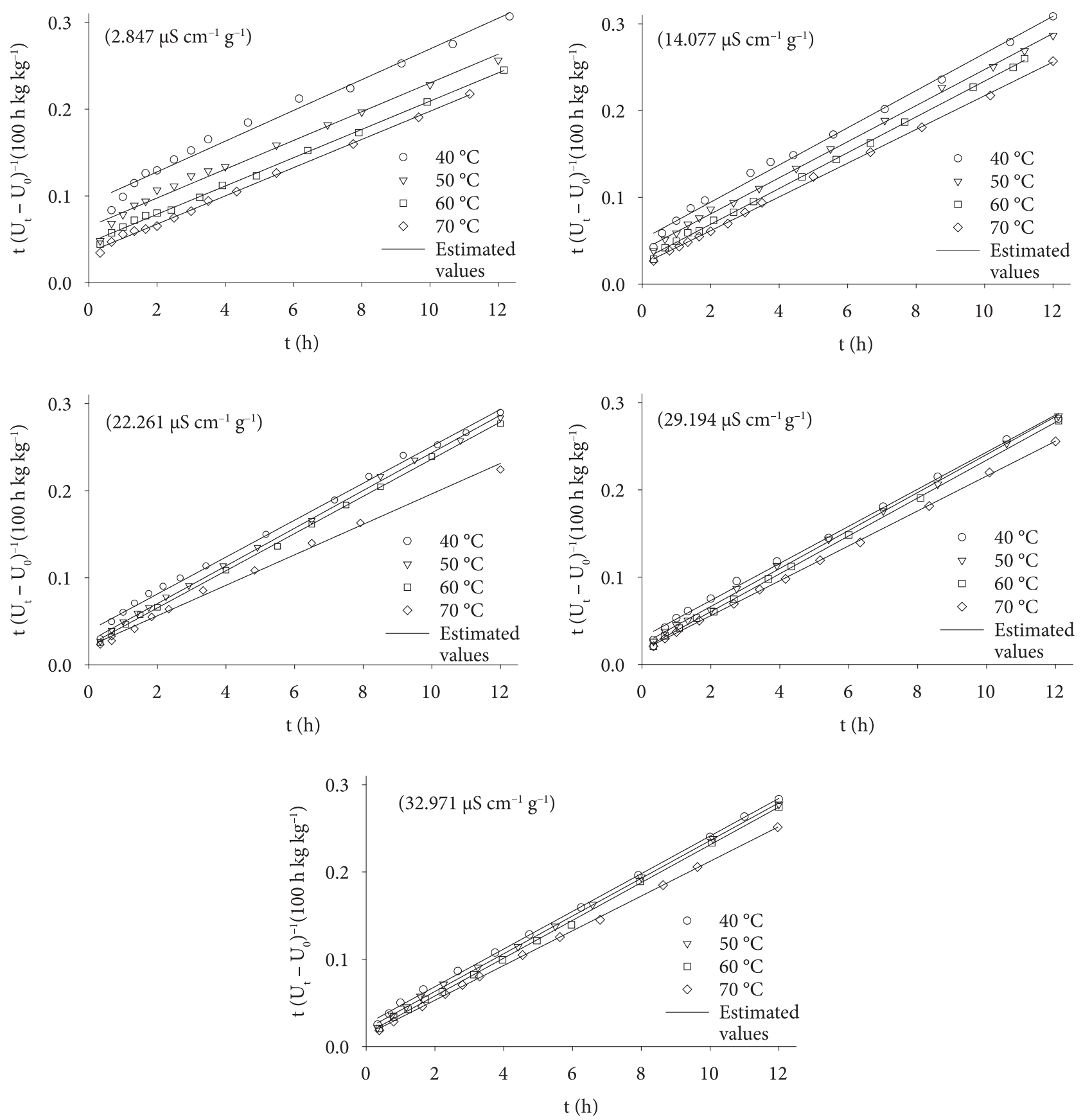

Figure 2. Values of linearized Peleg model for the moisture content during the hydration process under different temperatures and mechanical damage levels of the corn kernels.

criterion for non-linear methods (KASHANINEJAD et al., 2007; CUNNINGHAM; McMINN; RICHARDSON, 2007). Considering the variance range for the moisture content of the corn kernels, the model presented satisfactory values for the standard error of estimate and the estimated data variability less than $10 \%$ for all of the soaking conditions, which are recommended for the use of non-linear models (MADAMBA; DRISCOLLB; BUCKLEB, 1996; CUNNINGHAM; MCMINN; RICHARDSON, 2007).
The behavior of the Peleg constant rate $\left(C_{1}\right)$ as a function of temperature and mechanical damage level is shown in Figure 3.

The Peleg's constant rate decreased with the increase of temperature, and this decrease was more significant for the kernels with lower levels mechanical damage (Figure 3). It was further observed that the $C_{1}$ constant tended to stabilize at higher temperatures and, in addition, the higher the level of mechanical damage, the lower is this value for the same temperature. 
This behavior exhibited by $C_{1}$ constant as function of temperature is commonly observed in water absorption modeling studies (RESENDE; CORRÊA, 2007; CUNNINGHAM; McMINN; RICHARDSON, 2007; KASHIRI; KASHANINEJAD; AGHAJANI, 2010; MIŠLJENOVIĆ et al., 2011).

The $C_{1}$ constant in the Peleg model is related to the mass transfer rate, and the lower is this value, the higher the initial rates of water absorption (TURHAN; SAYAR; GUNASEKARAN, 2002; MIŠLJENOVIĆ et al., 2011). This coefficient may even be related to the diffusion coefficient (CUNNINGHAM; McMINN; RICHARDSON, 2007; MASKAN, 2002). According to the values found for this constant, it is possible to verify that the physical integrity of the product significantly influences the initial water absorption rate during the soaking process. It is possible that structurally damaged products present cracks, forming preferential pathways for water that are occupied in the beginning of the soaking process. Thus, for hydration processes under sub-gelatinization temperatures, which is the case of wet milling process of corn, the effect of the mechanical damage on the initial water absorption by agricultural products might be as important as the effect of the temperature variation.

The behavior of the Peleg constant capacity $\left(C_{2}\right)$ as a function of temperature and mechanical damage level is presented in Figure 4.

According to Figure 4, it can be seen that the Peleg constant capacity $\left(C_{2}\right)$ decreased with the increase in temperature, regardless of the damage level of the product; in agreement with the majority of the studies on this topic (RESENDE;
CORRÊA, 2007; CUNNINGHAM; McMINN; RICHARDSON, 2007; KASHIRI; KASHANINEJAD; AGHAJANI, 2010; MIŠLJENOVIĆ et al., 2011). The $C_{2}$ constant had higher values for the kernels with higher damage levels, and the magnitudes of these constants was lower for the kernels with no induced damage (control). In addition, it was verified that for the undamaged kernels, $C_{2}$ constant presented a gradual decrease in relation to the temperature, while the damaged kernels presented a significant decrease in this constant value at the temperature of $70^{\circ} \mathrm{C}$.

Peleg's capacity constant, $C_{2}$, is related to the maximum capacity of water absorption, and the lower is this value, the higher is the water absorption by the product (MASKAN, 2002). According to this, it is possible to state that the physical damage of the kernels has direct influence not only on the initial water absorption rate, but also on the total amount of water that the product is able to absorb. Another important observation is that even if the product reaches the gelatinization temperature of the starch (between 60 and $70{ }^{\circ} \mathrm{C}$ ) and thus the cracks are reconstituted, the product fails to reach the equilibrium moisture content of a product with no mechanical damage.

The values of equilibrium moisture content estimated by the Peleg model for each soaking condition are shown in Table 2.

It can be seen in Table 2 that, for all the conditions in which the corn kernels presented some level of mechanical damage, the equilibrium moisture content reached was significantly the same, except for the temperature of $70{ }^{\circ} \mathrm{C}$. On the other hand, for the corn kernels with no induced mechanical

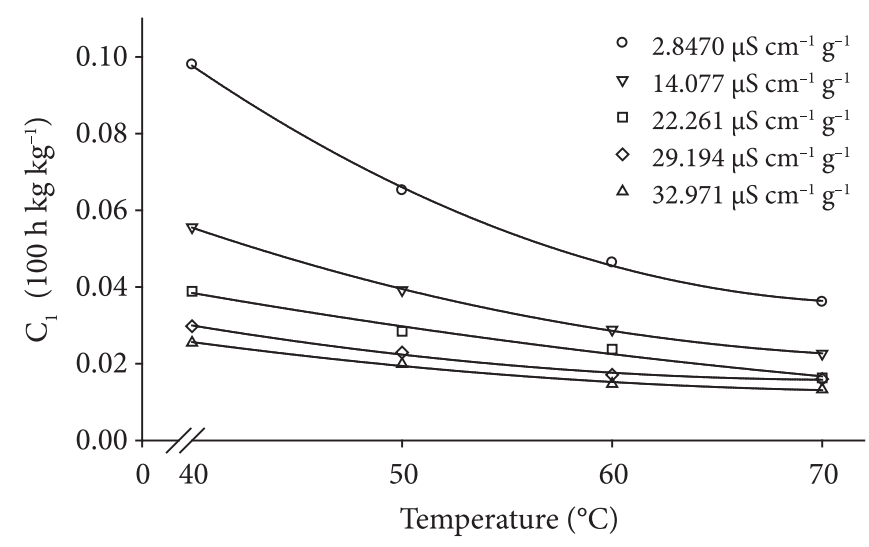

Figure 3. Variation of the Peleg rate constant $\left(C_{1}\right)$ as a function of temperature and mechanical damage levels for the corn kernels analyzed.

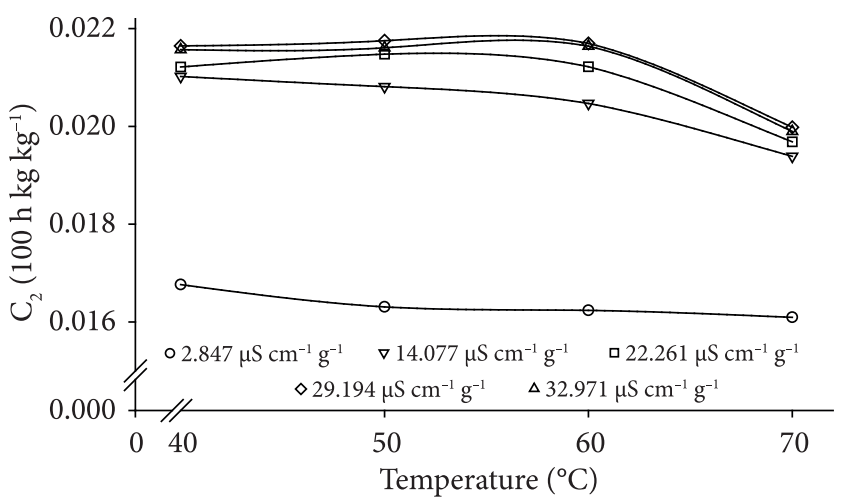

Figure 4. Variation of the Peleg capacity constant $\left(C_{2}\right)$ as a function of temperature and mechanical damage levels for the corn kernels analyzed.

Table 2. Estimated values of the equilibrium moisture content (\% d.b.) for each mechanical damage level and temperature analyzed.

\begin{tabular}{ccccc}
\hline $\begin{array}{c}\text { Mechanical damage levels } \\
\left(\mu \mathrm{S} \mathrm{cm}^{-1} \mathrm{~g}^{-1}\right)\end{array}$ & 40 & 50 & \multicolumn{3}{c}{ Temperature $\left({ }^{\circ} \mathrm{C}\right)$} \\
\cline { 2 - 5 } & $74.0^{\mathrm{aA}}$ & $76.19^{\mathrm{abA}}$ & $77.45^{\mathrm{bA}}$ & 70 \\
14.847 & $62.63^{\mathrm{aB}}$ & $63.56^{\mathrm{aB}}$ & $65.09^{\mathrm{aB}}$ & $68.15^{\mathrm{bA}}$ \\
22.261 & $62.68^{\mathrm{aB}}$ & $62.42^{\mathrm{aB}}$ & $62.99^{\mathrm{aB}}$ & $67.33^{\mathrm{bB}}$ \\
29.194 & $62.93^{\mathrm{aB}}$ & $62.70^{\mathrm{aB}}$ & $62.59^{\mathrm{aB}}$ & $69.85^{\mathrm{bB}}$ \\
32.971 & $63.09^{\mathrm{aB}}$ & $63.01^{\mathrm{aB}}$ & $62.94^{\mathrm{aB}}$ & $66.77^{\mathrm{bB}}$ \\
\hline
\end{tabular}

Averages followed by the lowercase letters in the row and uppercase letters in the column do not differ among themselves at a $5 \%$ probability by the Tukey test. 
damage (control), no difference was observed between the equilibrium moisture content reached for the temperatures of 50,60 , and $70{ }^{\circ} \mathrm{C}$. It was also found that for the same soaking temperature, the equilibrium moisture content reached by the corn kernels with no mechanical damage was higher than that reached by the damaged product. Therefore, although the initial water absorption capacity is higher, the higher is the level of mechanical damage (as previously discussed), the lower is the equilibrium moisture content reached during the soaking process by the damaged corn kernels when compared to that of the undamaged kernels.

\section{Conclusions}

Based on the results obtained and the conditions of this experiment, the conclusion is that the structural changes caused by the mechanical damage in corn kernels changed the water absorption rates in the product, and it was higher for the most damaged corn kernels. The Peleg model was well adjusted to the experimental data presenting satisfactory values for the statistical parameters analyzed, regardless of the damage level of the corn kernels. It was also observed that the equilibrium moisture content estimated by the Peleg model virtually did not vary with temperature increase, mainly for the mechanically damaged corn kernels.

\section{References}

BELLO, M.; TOLABA, M. P.; SUAREZ, C. Factors affecting water uptake of rice grain during soaking. Lebensmittel-Wissenschaft und-Technologie, v. 37, p. 811-816, 2004.

BRASIL. Ministério da Agricultura e Reforma Agrária. Regras para análise de sementes. Brasília: SNDA/DNDV/CLAV, 1992. 365 p.

CUNNINGHAM, S. E.; McMINN, W. A. M.; RICHARDSON, P. S. Modelling water absorption of pasta during soaking. Journal of Food Engineering, v. 82, p. 600-607, 2007. http://dx.doi. org/10.1016/j.jfoodeng.2007.03.018

DOWD, M. K. Improvements to laboratory-scale maize wet-milling procedures. Industrial Crops and Products, v. 18, p. 67-76, 2003. http://dx.doi.org/10.1016/S0926-6690(03)00034-7

HAROS, M. et al. Effect of ground corn steeping on starch properties. European Food Research Technology, v. 222, p. 194200, 2006. http://dx.doi.org/10.1007/s00217-005-0102-2

HAROS, M.; TOLOBA, M. P.; SUAREZ, C. Influence of corn drying on its quality for the wet-milling process. Journal of Food Engineering, v. 60, p. 177-184, 2003. http://dx.doi.org/10.1016/ S0260-8774(03)00038-4

HAROS, M.; SUAREZ, C. Effect of drying, initial moisture and variety in corn wet milling. Journal of Food Engineering, v. 84, p. 473-481, 1997. http://dx.doi.org/10.1016/S0260-8774(97)00099-X

KASHANINEJAD, M. et al. Thin-layer drying characteristics and modeling of pistachio nuts. Journal of Food Engineering, v. 78, p. 98-108, 2007. http://dx.doi.org/10.1016/j.jfoodeng.2005.09.007

KASHIRI, M.; KASHANINEJAD, M.; AGHAJANI, N. Modeling water absorption of sorghum during soaking. Latin American Applied Research, v. 40, p. 383-388, 2010.

LOPES FILHO, J. F.; RAMOS, A. P.; ROMERO, J. T. Difusividade da água, dióxido de enxofre e ácido lático em grãos de milho durante a maceração para o processo de moagem úmida. Brazilian Journal of Food Technology, v. 9, n. 4, p. 257-263, 2006.

MADAMBA, P. S.; DRISCOLLB, R. H.; BUCKLEB, K. A. The Thinlayer Drying Characteristics of Garlic Slices. Journal of Food Engineering, v. 29, p. 75-97, 1996. http://dx.doi.org/10.1016/02608774(95)00062-3

MASKAN, M. Effect of processing on hydration kinetics of three wheat products of the same variety. Journal of Food Engineering, v. 52 p. 337-341, 2002. http://dx.doi.org/10.1016/S0260-8774(01)00124-8

MENDES, U. C.; RESENDE, O.; ALMEIDA, D. P. Form, size and volumetric expansion of adzuki beans (Vigna angularis) during soaking. Ciência e Tecnologia de Alimentos, v. 31, n. 3, p. 703709, 2011. http://dx.doi.org/10.1590/S0101-20612011000300023

MIŠLJENOVIĆ, N. M. et al. Application of Peleg model to study mass transfer during osmotic dehydration of apple in sugar beet molasses. Acta Periodica Technologica, v. 42, p. 91-100, 2011. http://dx.doi. org/10.2298/APT1142091M

MUÑOZ, I. et al. Rehydration kinetics at 5 and $15^{\circ} \mathrm{C}$ of dry salted meat. Journal of Food Engineering, v. 110, p. 465-471, 2012. http:// dx.doi.org/10.1016/j.jfoodeng.2011.12.020

PELEG, M. An empirical model for the description of moisture sorption curves. Journal of Food Science, v. 52, p. 1216-1217 and 1219, 1988.

PEREZ, O. E. et al. Effect of steeping on the starch properties from ground whole corn. Journal of Food Engineering, v. 60, p. 281287, 2003. http://dx.doi.org/10.1016/S0260-8774(03)00049-9

RAMIREZ, E. C. et al. Engineering process and cost model for a conventional corn wet milling facility. Industrial Crops and Products, v. 27, p. 91-97, 2008. http://dx.doi.org/10.1016/j. indcrop.2007.08.002

RESENDE, O.; CORRÊA, P. C. Modelagem matemática do processo de hidratação de sementes de feijão. Acta Scientiarum. Agronomy, v. 29, p. 373-378, 2007.

RESIO, A. C.; AGUERRE, R. J.; SUAREZ, C. Hydration kinetics of amaranth grain. Journal of Food Engineering, v. 72, p. 247-253, 2006. http://dx.doi.org/10.1016/j.jfoodeng.2004.12.003

SOUZA, R. C. R.; ANDRADE, C. T. Investigação dos processos de gelatinização e extrusão de amido de milho. Polímeros, v. 10 , n. 1, p. $24-30,2000$. http://dx.doi.org/10.1590/S010414282000000100006

TURHAN, M.; SAYAR, S.; GUNASEKARAN, S. Application of Peleg model to study water absorption in chickpea during soaking. Journal of Food Engineering, v. 53, p. 153159, 2002. http://dx.doi. org/10.1016/S0260-8774(01)00152-2

VASUDEVA, S.; VISHWANATHAN, K. H. Hydration behaviour of food grains and modelling their moisture pick up as per Peleg's equation: Part II. Legumes. Journal of Food Science Technology, v. 47 , n. 1, p. 42-46, 2010. http://dx.doi.org/10.1007/s13197-0100013-5

VENGAIAH, P. C. et al. Hydration characteristics of wheat grain. Agricultural Engineering International: CIGR Journal, v. 14, n. 1, 2012 .

YILDIRIM, A.; ÖNER, M. D.; BAYRAM, M. Modeling of water absorption of ultrasound applied chickpeas (Cicer arietinum L.) using Peleg's equation. Journal of Agricultural Sciences, v. 16, p. 278-286, 2010.

YILDIRIM, A.; ÖNER, M. D.; BAYRAM, M. Fitting Fick's model to analyze water diffusion into chickpeas during soaking with ultrasound treatment. Journal of Food Engineering, v. 104, p. 134142, 2011. http://dx.doi.org/10.1016/j.jfoodeng.2010.12.005 